\title{
Adhesion of high and low virulence Flavobacterium psychrophilum strains to isolated gill arches of rainbow trout Oncorhynchus mykiss
}

\author{
Amin Nematollahi*, Annemie Decostere, Frank Pasmans, Richard Ducatelle, \\ Freddy Haesebrouck
}

Laboratory of Veterinary Bacteriology and Mycology and Laboratory of Veterinary Pathology, Faculty of Veterinary Medicine, Ghent University, Salisburylaan 133, 9820 Merelbeke, Belgium

\begin{abstract}
The ability of Flavobacterium psychrophilum to adhere to the gill tissue of rainbow trout Oncorhynchus mykiss was evaluated. A gill perfusion model was adopted, offering a number of advantages compared to other in vitro as well as in vivo models. A comparison between the adhesion capacity of a high and low virulence F. psychrophilum strain was made. Experiments were additionally carried out to assess the influence of water quality (organic material, nitrite) and temperature on the adhesion process of the bacterial cells. The high virulence strain attached more readily to the gill tissue than did the low virulence strain. Moreover, the adherence of the high virulence strain of $F$. psychrophilum was influenced by a number of factors. These were immersion of the gill arches in water to which organic material or nitrite were added, and elevated temperature. The former 2 increased the adhesion ability, while the latter had a negative influence on the adherence process.
\end{abstract}

KEY WORDS: Flavobacterium psychrophilum - Rainbow trout · Adhesion · Gill tissue

\section{INTRODUCTION}

Flavobacterium psychrophilum (Bernardet et al. 1996) is the causative agent of rainbow trout fry syndrome (RTFS), a serious bacterial disease affecting hatchery reared rainbow trout Oncorhynchus mykiss fry and fingerlings in Europe, as well as Japan, Korea, Australia and Chile (Wakabayashi et al. 1991, Bustos et al. 1995, Rangdale 1995, Schmidtke \& Carson 1995, Lee \& Heo 1998, Dalsgaard \& Madsen 2000). In outbreaks of RTFS, mortalities of 10 to $70 \%$ are noted (Chua 1991, Santos et al. 1992).

In spite of the importance of Flavobacterium psychrophilum as a fish pathogen and the increasing significance of the disease, the data relating to its pathogenesis to provide sufficient scientific background for an efficient control strategy, and the first step of the interaction between this pathogen and its host, are lacking. The exact portal of entry remains unknown (Lorenzen 1994, Rangdale 1995), and is to a large extent rooted in the difficulties of reproducing the dis- ease under laboratory conditions by contact infection (cohabitation, immersion and oral/anal inoculation) (Borg 1960, Mudarris \& Austin 1989, Ostland et al. 1997, Decostere et al. 2000). As suggested by Dalsgaard (1993), further studies should determine the mechanisms of adhesion, their role in the pathogenesis of F. psychrophilum infections and the factors influencing the adherence process.

There are several ways a pathogen may adopt to enter its host's body: through the skin, gills and gut (Roberts 1976, Austin \& Austin 1999, Ellis 2001).

Previous data has suggested that the adhesion to the gill tissue might be an important initial step in the pathogenesis of Flavobacterium psychrophilum infections (Holt et al. 1993, Rangdale 1995, Amita et al. 2000). It has been reported that the gills may serve as a portal of entry for Cytophaga-like bacteria (CLB) (Roberts 1976). Chua (1991) and Bruno (1992) observed filamentous bacteria associated with the gills of fry suffering from RTFS. Other research groups likewise observed the abundant occurrence of F. psychrophilum in 
the gills which, as a result, became anaemic and very pale (Holt 1988, Rangdale 1995, Austin \& Austin 1999, Decostere et al. 2001, Tiirola et al. 2002).

In order to circumvent the difficulties when adopting a contact infection model and to document the importance of the gill tissue in the pathogenesis of the disease, in the present study a previously developed gill perfusion model was used (Decostere et al. 2002). This model approaches the in vivo situation and offers a means of maintaining the gill tissue intact for several hours, enabling study of the bacterium-host interactions under carefully controlled conditions. Using this model, the early stages of interaction between the bacterium and the gill tissue were evaluated and a comparison was made between a strain of high and low virulence. Additionally, the water quality and temperature of the bath in which the gill arch was suspended were varied and the influence on the adhesion process assessed.

\section{MATERIALS AND METHODS}

Fish. Ten rainbow trout Oncorhynchus mykiss of $800 \mathrm{~g}$ average weight were obtained from a commercial fish farm (Dilbeek, Belgium) with no history of RTFS. They were kept in a flowthrough system (2000 l tank) containing aerated well water $\left(14^{\circ} \mathrm{C}\right)$ for $3 \mathrm{wk}$ prior to experimentation $(\mathrm{pH} 7.6$; dissolved oxygen 9 ppm; total hardness 100 ppm; $\mathrm{NH}_{3}<0.01$ ppm; $\mathrm{NO}_{2}<$ $0.01 \mathrm{ppm})$. The fish were fed daily with a commercial diet (Trouvit Perle Response 2000, Trouw) until 2 d before the start of the experiments. All fish were clinically assessed upon arrival and the skin, fins and gills were sampled for parasitological examination. Swabs from the skin and gills were taken and streaked onto Shieh agar (Shieh 1980) for the evaluation of the presence of Flavobacterium psychrophilum. Plates were incubated at $15^{\circ} \mathrm{C}$ for $4 \mathrm{~d}$. The fish were found to be free of external parasite infestations and F. psychrophilum was not isolated from any of the collected samples.

Bacterial strains. Two Flavobacterium psychrophilum strains were used: Dubois and 99/10A. Strain Dubois was isolated from the spleen in an outbreak of RTFS in Belgium following a high mortality (70\%) among the affected rainbow trout fry. Strain 99/10A was recovered in Denmark from the internal organs of healthy rainbow trout (Madsen \& Dalsgaard 1998). Both strains were stored virtually immediately following in vivo isolation. Experimental infection studies using intraperitoneal injection proved that Strain Dubois was a highly virulent strain, whereas Strain 99/10A was of low virulence (Madsen \& Dalsgaard 1998, Lammens et al. 2000).
Stock suspensions of the 2 strains were stored at $-70^{\circ} \mathrm{C}$. After thawing, the bacteria were grown for $4 \mathrm{~d}$ in $4 \mathrm{ml}$ of Shieh broth at $15^{\circ} \mathrm{C}$. Subsequently, subcultures were incubated for $4 \mathrm{~d}$ at $15^{\circ} \mathrm{C}$. The cultured broth was centrifuged $\left(3000 \xi \times g, 10 \mathrm{~min}, 15^{\circ} \mathrm{C}\right)$ and the resulting pellet and supernatant were separated. The pellet was re-suspended in phosphate-buffered saline (PBS). The suspension was checked for purity and the number of colony forming units (CFU) was determined by plating 10-fold serial dilutions on Shieh agar plates.

Gill perfusion model. The model system used has been previously described (Decostere et al. 2002). Briefly, the fish were anaesthetised using a benzocain solution in ethanol (w/v $\left.\left[0.1 \mathrm{~g} \mathrm{ml}^{-1}\right]\right)$, injected intraperitoneally with heparin (5000 IU kg-1) and allowed to recover. Thirty min later, the fish were killed using an overdose of the benzocain solution. The heart and ventral aorta were exposed by ventral dissection. A haemostat was clamped onto the ventral aorta to prevent the afferent arteries from flooding the operation field with blood when dissecting the gill arches. The opercula on both sides were removed and the first 2 or 3 gill arches of both sides were excised and put into petri dishes filled with Ringer solution at $12^{\circ} \mathrm{C}$. The smaller dorsal part of each gill arch was cut off in order to remove the bend, since the latter creates a resistance to flow, jeopardizing an efficient perfusion. Thereafter, the afferent (ventral) and efferent (dorsal) arteries of the gill arch were cannulated and perfusion was begun at a flow of $1 \mathrm{ml} \mathrm{min}{ }^{-1} \mathrm{arch}^{-1} \mathrm{~kg}^{-1}$ body weight. The perfusion fluid was Cortland + dextran $1 \%$ (MW 500000; Sigma), which was delivered by means of a drip (Decostere et al. 2000). Subsequently, each gill arch was placed in a solution containing enrofloxacin (10 $\mathrm{mg} \mathrm{l}^{-1}$ ) for $15 \mathrm{~min}$ followed by a bath in colistin (2000 IU ml$^{-1}$ ) for $15 \mathrm{~min}$. The gills were then rinsed 3 times in sterile PBS and each gill arch was suspended separately in an aerated organ bath. The organ bath consisted of a circular organ chamber filled with Ringer solution (volume $=100 \mathrm{ml}$ ) and was surrounded by a water jacket at constant temperature (Decostere et al. 2000). Dissection and cannulation of each gill arch was completed within 5 min. Perfusion was carried out for 30 min to allow the gills to recover from the most acute effects of the procedure. Thereafter, the isolated gill arches were used in adhesion assays as described below.

Experimental design. The first experiment (Expt I) investigated the possible differences in adhesion abilities between the high and low virulence Flavobacterium psychrophilum strains. For that purpose, the first 3 gill arches of both sides of a rainbow trout were each placed in a separate organ bath with Ringer solution at $12^{\circ} \mathrm{C}$ and perfused as described above. 
The high- (Dubois) or low- (99/10A) virulence Flavobacterium psychrophilum strains were added to the baths containing the first and second left and right gill arches, respectively. The final titer of the bacterium in each organ bath was $10^{7} \mathrm{CFU} \mathrm{ml}{ }^{-1}$. Sterile PBS was added to the organ bath of the third left gill arch. Nothing was added to the organ bath of the third right gill arch. Both third gill arches served as controls. After adding the bacterial suspension, gill arches were incubated for $60 \mathrm{~min}$. During the experiments, the perfused gills were observed macroscopically. After the incubation period, a Gram stain was made of any occurring abnormalities and the gill arches were processed for examination of adhesion as described below. The experiment was repeated 4 times.

Expt II was carried out to determine the influence of water quality and water temperature on the ability of Flavobacterium psychrophilum to adhere to the branchial tissue. The first 2 gill arches of both the left and right side of 2 rainbow trout were each placed in an organ bath containing Ringer solution and perfused as described above. The temperature of the bath of the first left gill arch of both fish was $18^{\circ} \mathrm{C}$. All other arches were incubated at $12^{\circ} \mathrm{C}$. Nothing was added to the bath of the second left gill arch. To the bath of the first right gill arch of both rainbow trout, $5 \mathrm{mg} \mathrm{l}^{-1}$ nitrite was added. The bath of the second right gill arch was supplemented with $2 \mathrm{~g} \mathrm{l}^{-1}$ organic material. The latter consisted of a mixture of food residues and faeces and was collected from the bottom of the fish tank. The slurry was sterilised $\left(121^{\circ} \mathrm{C}\right.$ for $\left.15 \mathrm{~min}\right)$ before addition to the organ bath. After 30 min perfusion, all gill arches of the first rainbow trout were incubated with F. psychrophilum Strain Dubois and those of the second rainbow trout with Strain 99/10A. The final titer of F. psychrophilum in each bath was $10^{7} \mathrm{CFU} \mathrm{ml}{ }^{-1}$. The gill arches were incubated for $60 \mathrm{~min}$ and thereafter processed for examination of adhesion as described below. A Gram stain was again made of any occurring abnormalities after the incubation period. The experiment was repeated 3 times.

Processing of the gills for examination of adhesion. After the incubation period, the gill arch was cut in 2 equally sized pieces. A randomly selected piece was washed 3 times in square petri dishes containing $40 \mathrm{ml}$ of sterile PBS at $15^{\circ} \mathrm{C}$ and was then placed into preweighed vials containing $2 \mathrm{ml}$ of sterile PBS. The vials were weighed to the nearest $0.01 \mathrm{~g}$. The contents of the vials were placed in a sterile mortar. The gill was macerated and 10-fold serial dilutions of the gill slurry were made in PBS. Fifty microliters of each concentration were inoculated on Shieh agar. For each dilution, 3 plates were used. After $4 \mathrm{~d}$ of incubation at $15^{\circ} \mathrm{C}$, viable counts were made. Consequently, the average number of $\mathrm{CFU} \mathrm{g^{-1 }}$ of 3 replicate inoculations was taken and used to calculate the mean of the 3 or 4 experiments.

For the histopathological examination, the second piece of the gill arch was placed in $4 \%$ phosphate buffered formaldehyde for $24 \mathrm{~h}$. The tissues were subsequently sectioned and stained with Giemsa and haematoxylin and eosin (H\&E). The sections were examined by light microscopy.

Statistical analysis. Differences in $\mathrm{CFU} \mathrm{g}^{-1}$ gill tissue within each experiment were compared using a 1-way ANOVA (computer program Sigma Stat, Analytical Software). In the first experiment, the values for the high and low virulent strain were compared with each other. In the second experiment, for each individual Flavobacterium psychrophilum strain, each value was compared with the value obtained when Ringer at $12^{\circ} \mathrm{C}$ (control) was used as bathing fluid. A significance level of 0.05 was accepted.

\section{RESULTS}

\section{Adhesion of high and low virulence strains of Flavobacterium psychrophilum (Expt I)}

The gill arches inoculated with Flavobacterium psychrophilum Strain Dubois showed white threads on top of the primary lamellae after exposure to the agent. When a Gram stain was made of these threads, masses of long, slender Gram-negative bacteria were identified. The control gill arches and the gill arches challenged with 99/10A did not display similar structures.

Results of the bacteriological examination of the gills exposed to Strain Dubois and 99/10A are given in Table 1 . There was an overall statistically significant $(\mathrm{p}<0.05)$ difference between the number of $\mathrm{CFU} \mathrm{g}^{-1}$ gill tissue of the holobranchs challenged with Strain Dubois on one hand, and Strain 99/10A on the other.

Upon histopathological examination a similar trend was evident. Branchial arches challenged with strain Dubois showed numerous clusters of long, slender bacteria principally situated at the distal end of the filaments (Fig. 1). These bacterial cells were packed within areas of lamellar distortion, sloughing of the surface epithelium and necrotic cells. In sections of gill arches exposed to Strain $99 / 10 A$, only very occasionally filamentous bacteria could be observed. In control gill sections, no other bacteria were noted. Both the Strain 99/10A inoculated and control gills were in an overall healthy condition.

\section{Influence of water quality and temperature (Expt II)}

On the gill arches exposed to Strain Dubois at $12^{\circ} \mathrm{C}$, irrespective of the presence of nitrite or organic mater- 
Table 1. Oncorhynchus mykiss. Results of the bacterial titrations of gill arches exposed to $10^{7} \mathrm{CFU}^{-1}$ of Flavobacterium psychrophilum Strains Dubois and 99/10A. *Each bacterial titer value represents the mean $( \pm \mathrm{SD})$ of 3 or 4 independent experiments

\begin{tabular}{|c|c|c|c|c|}
\hline Expt & $\begin{array}{c}\text { Flavobacterium psychrophilum } \\
\text { strain }\end{array}$ & Bathing fluid & $\begin{array}{c}\text { Incubation } \\
\text { temperature }\left({ }^{\circ} \mathrm{C}\right)\end{array}$ & $\begin{array}{c}\text { Bacterial titer } \\
\log _{10} \text { cfu g-1 gill tissue* }\end{array}$ \\
\hline \multirow[t]{2}{*}{ I } & Dubois & Ringer & 12 & $6.64( \pm 0.41)^{\mathrm{a}}$ \\
\hline & $99 / 10 \mathrm{~A}$ & Ringer & 12 & $5.42( \pm 0.40)$ \\
\hline \multirow[t]{8}{*}{ II } & Dubois & Ringer & 18 & $4.47( \pm 0.09)^{b}$ \\
\hline & Dubois & Ringer & 12 & $5.68( \pm 0.20)$ \\
\hline & Dubois & Ringer + organic matter & 12 & $7.70( \pm 0.13)^{\mathrm{b}}$ \\
\hline & Dubois & Ringer $+5 \mathrm{mg} \mathrm{l}^{-1}$ nitrite & 12 & $6.79( \pm 0.10)^{\mathrm{b}}$ \\
\hline & $99 / 10 \mathrm{~A}$ & Ringer & 18 & $4.47( \pm 0.09)^{b}$ \\
\hline & $99 / 10 \mathrm{~A}$ & Ringer & 12 & $4.60( \pm 0.15)$ \\
\hline & 99/10A & Ringer + organic matter & 12 & $4.63( \pm 0.30)$ \\
\hline & 99/10A & Ringer $+5 \mathrm{mg} \mathrm{l}^{-1}$ nitrite & 12 & $4.30( \pm 0.08)$ \\
\hline
\end{tabular}

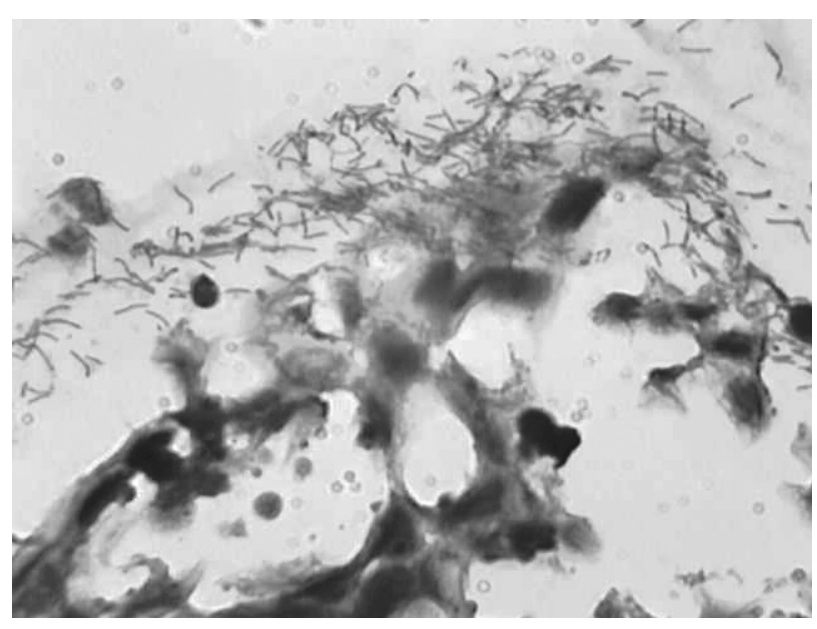

Fig. 1. Clusters of Flavobacterium psychrophilum Strain Dubois associated with the tip of the primary lamella of an infected holobranch of rainbow trout Oncorhynchus mykiss. Note the typical long and slender morphology of the bacterial cells and the necrotic tissue (1000×, Giemsa)

ial, the formation of thread-like structures was evident. When the gill tissue was exposed to the same strain at $18^{\circ} \mathrm{C}$, only tiny and delicate filament-like structures were observed. These structures were not noted in gill arches inoculated with Strain 99/10A.

Results of the bacteriological titrations are given in Table 1. Concerning Strain Dubois, bacterial titers were significantly $(\mathrm{p}<0.05)$ higher when nitrite or organic material was added to the organ bath. In gill arches inoculated with Strain 99/10A, no significant differences were observed whether or not nitrite or organic material was supplemented. Upon histological examination, an intimate association of the pathogen with the gill tissue was seen only in gill arches exposed to Strain Dubois at $12^{\circ} \mathrm{C}$ regardless of the presence of organic material or nitrite, but not on the gill arches exposed to Strain 99/10A and the control gill arches.

\section{DISCUSSION}

There have been various reports noting the difference in virulence among Flavobacterium psychrophilum strains (Dalsgaard 1993, Lorenzen 1994, Madsen \& Dalsgaard 2000). Nevertheless, there is an undeniable paucity of information concerning the actual factors determining virulence. Especially in terms of early pathogenesis, data remain very scarce both in number and relevance.

In the present study, the early stages of interaction between Flavobacterium psychrophilum and the gill tissue were investigated and a comparison was made between strains of high and low virulence. For that purpose, one could opt for the use of methods, which address a single substrate for bacterial adhesion such as gill-tissue culture cells. Gill cells in culture are, however, restricted to respiratory epithelial cells. Chloride and mucous cells, the other 2 cell types that compose the gill epithelium do not survive in culture. Additionally, the surfaces of the cultured cells may eventually present different proteins from in vivo cells, especially in terms of distribution and accessibility of receptors. Furthermore, overall gill organisation, architecture, and the mucous layer covering the gill epithelium are completely lost (Decostere 1999, Knudsen et al. 1999). The mucous layer is an important barrier to potential pathogen attachment in vivo and therefore in vitro models may be more susceptible to bacterial adherence (Ofek \& Doyle 1994, Decostere et al. 2002). Conversely, the tendency of bacteria to associate with the mucous layer has been widely reported. In either case, the mucous layer is essential for a proper evaluation of the adherence process. In this respect, mere mucus may be adopted. However, the collection of mucus is time-consuming, and may lead to the destruction/ reduction of receptors and bacterial ligands (Pärt \& Bergström 1995, Knudsen et al. 1999). In order to pre- 
vent all these potential artefacts, a gill perfusion model was adopted. This gill model enabled us to bypass the often failing and hard-to-standardize contact infection experiments and still validate the role of the holobranchs in the establishment of invasion of this bacterial pathogen. The resulting data prove that the high virulence strain has a significantly greater capacity to adhere to the gill tissue than does the low virulence strain. The changes seen after incubation of the gill arches with the highly virulent strain include oedema and epithelial lifting followed by sloughing of the epithelial cells and disintegration of the lamellar tissue. This is indicative of a direct toxic effection of the gill tissue which has not been reported before for F. psychrophilum. This phenomenon has been noted for F. columnare (Decostere 1999), the warm water counterpart of F. psychrophilum.

Various facts, when joined together, undoubtedly point towards the importance of the gill tissue in the early pathogenesis of RTFS. These include the observation of gill lesions packed with Flavobacterium psychrophilum in natural outbreaks of RTFS (Chua 1991, Bruno 1992, Tiirola et al. 2002), a phenomenon which was likewise noted in the gill-perfusion model experiments for the highly virulent strain.

The apparent correlation between adhesion capacity and virulence, as demonstrated for the first time in the present study, also adds greatly to this. One has also to keep in mind that the gill tissue is indeed prone to pathogens, as it has a huge surface area and a minimal diffusion distance to capillaries, lending the noxious agent fairly quick and easy access to the blood stream.

Besides offering the above listed advantages, the gill perfusion model represents a valuable alternative for the use of live fish in research. The above model successfully adopts the 3 ' $\mathrm{R}$ ' concept (replacement, reduction and refinement) of Russell \& Burch (1959), a basic and important concept defining welfare in animal experimentation. It also reduces the number of animals necessary in experiments, since one can use up to 6 gill arches per fish, that is 3 arches per side. The 4 th gill arch was not adopted due to its smaller size and deeper position. Likewise, the gill arches need to be of sufficient size to be able to catheterize the arteries fairly easily, since too long an attempt leads to extended periods of ischemia, jeopardizing the integrity of the gill tissue. Additionally, the animal is euthanized immediately before the dissection of the gill arches, and hence not subjected to experimental infections. This markedly reduces the amount of pain and distress suffered by the animal, which makes the gill perfusion model a suitable example of the concept of refinement.

In order to be sure that this model fully represents the in vivo situation, one could repeat the adhesion experiments by adopting live fish and compare the obtained results with the in vitro situation, and hence possibly fully validate the gill perfusion model. This has been done for Flavobacterium columnare in carp Cyprinus carpio, where a positive correlation was found between the results obtained in live fish and those using the gill perfusion model (Decostere 1999).

The effect of several parameters, related to both fish and environmental conditions, on the course of RTFS has been studied by research groups (Dalsgaard 1993, Holt et al. 1993, Lorenzen 1994, Soltani \& Burke 1994, Decostere et al. 2000). These groups consented unanimously to the fact that inadequate environmental conditions very often cause an outbreak of RTFS. However, to our knowledge, there is no information whatsoever on the mechanism by which these parameters exert their influence. In this study, high levels of nitrite and the presence of organic material proved to enhance the adhesion of the high virulence Flavobacterium psychrophilum strain. The question which naturally arises is, how the change in water quality influences the adherence process of $F$. psychrophilum, hence augmenting infection and colonization rates. One possible hypothesis may be that the altered environmental parameters induce a change to the bacterial cells themselves. It is true that many bacteria respond in a coordinate manner to environmental changes. External stimuli, sensed by receptors, are transduced to regulatory proteins, which participate in welldefined pathways of gene expression by varying their structure and mode of action. The network of environmental signal transduction is responsible for a fine and continuous communication between the host and the pathogenic bacteria (Soltani \& Burke 1994, Williams et al. 1995, Austin \& Austin 1999). Given that, the majority of the genes encoding adherence molecules undergo environmental regulation (Hacker 1996). In addition, it can be speculated that water quality may alter the bacterial surface of $F$. psychrophilum, resulting, in this case, in an increased adherence capacity.

A second hypothesis could be that a change in the environment alters the tissue of the host in such a way that the adhesion by Flavobacterium psychrophilum is facilitated. There are indeed numerous reports of gill structural changes induced by an altered environment (McDonald et al. 1991, Haaparanta et al. 1997). According to Laurent \& Perry (1991), the branchial tissue shows remarkable plasticity in the face of environmental disturbance manifested by rapidly occurring and pronounced changes in the morphometry of epithelial, mucous and chloride cells. There is, however, a lack of information on how these structural changes relate to changes at the molecular level (Pärt \& Bergström 1995). Further studies will have to address this. The gill perfusion may show its value in this research process. 
The adhesion of the low virulence strain was not enhanced by the presence of nitrite and organic material, again demonstrating the low capacity of this bacterium to adhere to the gill tissue under the present experimental conditions.

In the laboratory, Flavobacterium psychrophilum grows at temperatures between 4 and $20^{\circ} \mathrm{C}$. The disease usually appears when water temperatures are between 3 and $15^{\circ} \mathrm{C}$ and it has on various occasions been shown that the occurrence of RTFS is favoured by low environmental temperatures (Holt et al. 1989, Dalsgaard 1993, Lorenzen 1994). The higher capacity of F. psychrophilum to adhere to gill tissue at lower temperatures, as observed in the present studies, might play a role in this phenomenon. Again, the reason why this occurs needs to be clarified further in the future.

In conclusion, in the present study a positive correlation was documented between the virulence of 2 strains of Flavobacterium psychrophilum and their capacity to adhere to the gill tissue. Furthermore, the adhesion of the highly virulent $F$. psychrophilum strain to the gill tissue was influenced by environmental factors, which seem to play a role in the onset and/or severity of RTFS in vivo. Further studies will be directed to pinpoint the adherence mechanisms and receptors, aiming at elucidating the mechanisms through which environmental factors assert their influence on the adhesion process.

Acknowledgements. Mr. C. Puttevils is acknowledged for preparing the gill sections and for his skilled technical assistance. Thanks also to the Ministry of Science, Research and Technology of Iran for providing a scholarship to A.N.

\section{LITERATURE CITED}

Amita K, Hoshimo M, Honma T, Wakabayashi H (2000) An investigation on distribution of Flavobacterium psychrophilum in the Umikava River. Fish Pathol 35:193-197

Austin B, Austin DA (1999) Bacterial fish pathogens: disease of farmed and wild fish. Praxis Publishing, Chichester

Bernardet JF, Sergers P, Vancanneyt M, Berthe F, Kersters K, Vandamme P (1996) Cutting a gordian knot: emended classification and description of the Genus Flavobacterium, emended description of the family Flavobacteriaceae, and proposal of Flavobacterium hydatis nom. nov. (Basonym, Cytophaga aquatilis Strohl and Tait 1978). Int J Syst Bacteriol 46:128-148

Borg AF (1960) Studies on myxobacteria associated with diseases in salmonid fishes. J Wildl Dis 8:1-85

Bruno DW (1992) Cytophaga psychrophila (= Flexibacter psychrophilus) (Borg), histopathology associated with mortalities among farmed rainbow trout, Oncorhynchus mykiss (Walbaum) in the UK. Bull Eur Assoc Fish Pathol 12: 215-216

Bustos PA, Calbuyahue J, Montaña J, Opazo B, Entrala P, Solervisenc R (1995) First isolation of Flexibacter psychrophilus, as causative agent of rainbow trout fry syn- drome (RTFS), producing rainbow trout mortality in Chile. Bull Eur Assoc Fish Pathol 15:162-164

Chua FHC (1991) A study on the rainbow trout fry syndrome. MSc thesis, University of Stirling

Dalsgaard I (1993) Virulence mechanisms in Cytophaga psychrophila and other Cytophaga-like bacteria pathogenic for fish. Annu Rev Fish Dis 1:127-144

Dalsgaard I, Madsen L (2000) Bacterial pathogens in rainbow trout, Oncorhynchus mykiss (Walbaum), reared at Danish freshwater farms. J Fish Dis 23:199-209

Decostere A (1999) Flavobacterium columnare infections in fish: the agent and its adhesion to the gill tissue. $\mathrm{PhD}$ thesis, Ghent University

Decostere A, Lammens M, Haesebrouck F (2000a) Difficulties in experimental infection with Flavobacterium psychrophilum in rainbow trout (Oncorhynchus mykiss) using immersion, oral and anal challenges. Res Vet Sci 69: 165-169

Decostere A, Turnbull JF, Ducatelle R, Haesebrouck F (2000b) Development of a gill perfusion apparatus for studying the interaction of fish pathogens with gill tissue. Altern Lab Anim 28:53-61

Decostere A, D'Haese E, Lammens M, Nelis H, Haesebrouck F (2001) In vivo study of phagocytosis, intracellular survival and multiplication of Flavobacterium psychrophilum in rainbow trout, Oncorhynchus mykiss (Walbaum), spleen phagocytes. J Fish Dis 24:481-487

Decostere A, Henckaerts K, Haesebrouck F (2002) An alternative model to study the association of rainbow trout (Oncorhynchus mykiss L.) pathogens with the gill tissue. Laboratory Animals 36:396-402

Ellis AE (2001) The immunology of teleosts. In: Roberts RJ (ed) Fish pathology. Harcourt Publishers, London, p 133-150

Haaparanta A, Valtonen ET, Hoffman RW (1997) Gill anomalies of perch and roach from four lakes differing in water quality. J Fish Biol 50:575-591

Hacker J (1996) Microbial pathogenicity factors as parts of global regulatory networks. Acta Microbiol Immunol Hung 43:19-24

Holt RA (1988) Cytophaga psychrophila, the causative agent of bacterial cold-water disease in salmonid fish. PhD thesis, Oregon State University, Corvallis

Holt RA, Amandi A, Rohevec JS, Fryer JL (1989) Relation of water temperature to bacterial cold-water disease in coho salmon, chinook salmon, and rainbow trout. J Aquat Anim Health 1:94-101

Holt RA, Rohevec JS, Fryer JL (1993) Bacterial coldwater disease. In: Inglis V, Roberts RJ, Bromage NR (eds) Bacterial diseases of fish. Blackwell Scientific, Oxford, p 3-23

Knudsen G, Sorum H, Press CMcL, Olafsen JA (1999) In situ adherence of Vibrio spp. to cryosections of Atlantic Salmon, Salmo salar L., tissue. J Fish Dis 22:409-418

Lammens M, Decostere A, Haesebrouck F (2000) Effects of Flavobacterium psychrophilum and their metabolites on the oxidative activity of rainbow trout Oncorhynchus mykiss phagocytes. Dis Aquat Org 41:173-179.

Laurent P, Perry SF (1991) Environmental effects on fish gill morphology. Physiol Zool 64:4-25

Lee KB, Heo GJ (1998) First isolation and identification of Cytophaga psychrophila from cultured ayu in Korea. Fish Pathol 33:37-38

Lorenzen E (1994) Study on Flexibacter psychrophilus in relation to rainbow trout fry syndrome (RTFS). PhD thesis, Royal Veterinary and Agriculture University, Copenhagen

Madsen L, Dalsgaard I (1998) Characterization of Flavobacterium psychrophilum; comparison of proteolytic activity 
and virulence of strains isolated from rainbow trout (Oncorhynchus mykiss). In: Barnes AC, Davodson GA, Hiney MP, McIntosh D (eds) Methodology in fish diseases research. Fisheries Research Services, Aberdeen, p 45-52

Madsen L, Dalsgaard I (2000) Comparative studies of Danish Flavobacterium psychrophilum isolates: ribotypes, plasmid profiles, serotypes and virulence. J Fish Dis 23: 211-218

McDonald DG, Freda J, Cavdek V, Gonzales R, Zia S (1991) Interspecific differences in gill morphology of freshwater fish in relation to tolerance of low-pH environments. Physiol Zool 64:124-144

Mudarris M, Austin B (1989) Systemic disease in trout Scophthalmus maximus caused by a previously unrecognised Cytophaga like bacterium. Dis Aquat Org 6:161-166

Ofek I, Doyle RJ (1994) Bacterial adhesion to the cells and tissues. Chapman \& Hall, London

Ostland VE, Mcgrogan DC, Ferguson HW (1997) Cephalic osteochondritis and necrotic scleritis in intensively reared salmonids associated with Flexibacter psycrophilus. J Fish Dis 20:443-450

Pärt PL, Bergström E (1995) Primary cultures of teleost branchial epithelial cells. In: Wood CM, Shuttleworth TJ (eds) Cellular and molecular approaches to fish ionic regulation. Academic Press, New York, p 207-222

Rangdale RE (1995) Studies on rainbow trout fry syndrome (RTFS). PhD thesis, Ministry of Agriculture, Fisheries and Food, Weymouth; University of Stirling

Editorial responsibility: David Bruno,

Aberdeen, Scotland, UK
Roberts RJ (1976) Bacterial diseases of farmed fishes. In: Skinner FA, Carr JG (eds) Microbiology in agriculture, fisheries and food. Academic Press, London, p 55-61

Russell WMS, Burch RL (1959) The principles of human experimental technique. Menthun, London

Santos Y, Huntly PG, Turnbull A, Hastings TS (1992) Isolation of Cytophaga psychrophila (Flexibacter psycrophilus) in association with rainbow trout mortality in the United Kingdom. Bull Eur Assoc Fish Pathol 12:209-210

Schmidtke LM, Carson J (1995) Characteristics of Flexibacter psycrophilus isolated from Atlantic salmon in Australia. Dis Aquat Org 21:157-161

Shieh HS (1980) Studies on the nutrition of a fish pathogen, Flexibacter columnaris. Microbios Lett 13:129-133

Soltani M, Burke CM (1994) Responses of fish pathogenic Cytophaga/Flexibacter-like bacteria (CFLB) to environmental conditions. Bull Eur Assoc Fish Pathol 14:185-187

Tiirola M, Valtonen ET, Rintamaki-Kinnunen P, Kulomaa MS (2002) Diagnosis of flavobacteriosis by direct amplification of rRNA genes. Dis Aquat Org 51:93-100

Wakabayashi H, Horiuchi M, Bunya Y, Hoshiai G (1991) Outbreaks of coldwater disease in coho salmon in Japan. Fish Pathol 26:211-212

Williams P, Swift S, Modun B (1995) Continuous ambulatory peritoneal dialysis-associated peritonitis as a model device-related infection: phenotypic adaptation, the staphylococcal cell envelope and infection. J Hosp Infect 30:35-43

Submitted: November 27, 2002; Accepted: April 9, 2003

Proofs received from author(s): June 24, 2003 